\title{
The "Radiating Effects" of the ECtHR on Social Mobilizations Around Religion and Education in Europe: An Analytical Frame
}

\section{Effie Fokas}

Hellenic Foundation for European and Foreign Policy
(ELIAMEP)

Hellenic Observatory, London School of Economics

\section{Dia Anagnostou}

\author{
Hellenic Foundation for European and Foreign Policy \\ (ELIAMEP)
}

\section{Panteion University of Social and Political Sciences}

\begin{abstract}
A growing non-legal scholarship explores the domestic implementation of international court judgments in national law and policy. Yet little attention has been paid to the indirect effects of European Court of Human Rights (ECtHR) case law: namely, the ways in which its judgments may raise public consciousness, change how social actors articulate their claims, and/or prompt mobilization among civil society actors. This paper conceptualizes the significance of the indirect effects of ECtHR judgments in the domain of religion and education. Drawing on a constitutive approach to the law it explains the potential impact of such indirect effects. Second, it presents analytical concepts such as legal mobilization, which underpin the country-based case studies included in this symposium. Third, it provides an overview of the ECtHR religion and education-related case law which sets the stage for examining the nature and effects of the shadow of that case law in different country contexts.
\end{abstract}

Address correspondence and reprint requests to: Effie Fokas, Hellenic Foundation for European and Foreign Policy (ELIAMEP), Vassilisis Sofias 49, Athens 10676, Greece. E-mail: esfokas@eliamep.gr 


\section{INTRODUCTION}

Since the 1990s, the European Court of Human Rights (hereby ECtHR, or the Court) has become a central site where increasingly complex issues regarding religious freedom and diversity are contested. Before this court, local and national minority and majority faith communities, as well as NGOs of religious, non-religious, and other persuasions, have invoked human rights principles to challenge how European states approach and manage religious diversity. In response to a large number of petitions in the religious field, ${ }^{1}$ the ECtHR has pronounced authoritative and occasionally landmark judgments that state-parties to the European Convention of Human Rights (hereby ECHR or the Convention) have an obligation to implement domestically. Controversies related to religious symbols in public spaces (whether worn, as the headscarf, or on the wall, as in the crucifix), the teaching of religious education in public schools, or bioethics and social ethics such as the right to same-sex marriage, are all issues which touch upon deeply held religious beliefs and which have arisen before the ECtHR. In the context of such cases, the Court has been addressing some of the most divisive and emotive issues facing European societies. Do ECtHR judgemnts make a difference when it comes to religious pluralism on the ground?

The ECtHR's pronouncement of authoritative judgments in a variety of areas that encompass how states define and manage religious freedom and diversity exemplifies a global phenomenon in terms of the rise of international courts. One of the roles that these courts perform resembles that of constitutional courts in their scope and aim (Alter 2014, 16). In their de facto constitutional review role, courts like the ECtHR scrutinize national laws, policies, and practices for conformity with human rights principles. ${ }^{2}$ While a growing non-legal scholarship has begun to explore the domestic implementation of international court judgments in national law and policy (Keller and Stone Sweet 2008; Hillebrecht 2012; Anagnostou 2013; Anagnostou and Psychogiopoulou 2013), virtually no attention has been paid to their indirect effects ${ }^{3}$. Yet, the indirect effects of international human rights rulings are arguably far more important than the direct impact that they can have by means of their formal implementation by state authorities (Galanter 1983; Cassel 2001, 122; McCann 2004).

Indirect effects include the ways in which international human rights judgments may influence domestic debates in law, politics, and academia. They may raise public consciousness, change how social actors perceive and articulate their grievances and claims, empower national rights 
institutions, or prompt mobilization among civil society and other rights advocates. For example, studies show that decisions of high profile and authoritative courts like the U.S. Supreme Court prompt individuals to clearly elaborate their attitudes on an issue, crystallizing their views for or against the ruling and triggering a broad range of mobilization efforts (Johnson and Martin 1998). Alluding - at least in part-to the variable indirect effects of judicial rulings, some authors claim that the ECtHR in tandem with national constitutional courts play a significant role in redefining religious freedom in Europe (Richardson and Lee 2014, 292; see also Fokas 2015; Richardson 2015).

Specifically, in the domain of religion, a sizeable legal scholarship has explored the evolution of the ECtHR religion-related case law, its jurisprudential content and legal argumentation (See Evans 2001; Evans and Thomas 2006; Evans 2008; Mancini 2010; Ringelheim 2012; 2014). But there has been hardly any scholarly attention to the social and legal activism that emerges in response or in reaction to the ECtHR judgments around religion, as well as to a broader array of indirect effects that they may have in domestic struggles around religion. While the North American socio-legal literature serves as an excellent resource and inspiration, there are certainly significant challenges to grafting the relevant theories onto the European context. There are fundamental differences between the European and U.S. contexts, having to do with relative degrees of litigiousness, of embeddedness of religion in society and in politics, and of the visibility and popular awareness of the main courts in question (the U.S. Supreme Court, in most of the relevant North American literature, and the ECtHR $)^{4}$.

The primary purpose of this paper is to provide the conceptual and analytical frame for the study of the indirect effects of European human rights judgments in connection with religion and education, paving the way for the application of the primarily North American relevant socio-legal scholarship in the European context. The first part of this paper discusses the significance of the indirect effects of courts by drawing from a constitutive approach to law and rights. The second section defines and discusses basic analytical concepts, such as legal mobilization, which is the focus of the country-based case studies included in this symposium. And the third section provides a brief overview of the religion-related case law of the ECtHR specifically in reference to religion and education, thus setting the stage for the articles to follow in this symposium, which examines the nature and effects of the shadow of the religion and education-related case law presented here. 
Religion $^{5}$ and education form a particularly fruitful focus for the study of the Court's indirect effects. First, as noted by Fokas in this volume, "religion and education" represents a rapidly broadening domain of issues which touch on national as well as individual and family sensitivities: the domain goes well beyond the teaching, or not, of religion in schools (including the nature of such courses and the possibility of and conditions for exemption) and includes the way religion is taught in history courses, religious arguments against the teaching of sex education or evolution, and the presence of religious symbols in schools (whether worn by students or instructors or displayed in the schools). Thus, religion and education entail the subject of societal and political debates which are increasing in number and intensifying in effect at the local, national and international level.

Throughout Europe we see contention-often played out in legal settings-over whether religious schools can receive state funding, the indoctrinating character of courses on religious education, the demand for inclusion of atheist perspectives as part of public school curricula, just to name a few. Meanwhile, this is an area where the tension between the national and transnational levels is especially acute: considered a fundamental aspect of culture and identity, religion is a first candidate for falling within the realm of what should be addressed at the lowest level of governance (subsidiarity) and of what deserves an especially wide "margin of appreciation" within the ECtHR context. In the context of such heightened tension between the national and European level in this area, the indirect effects of the related case law can be expected to be both broad-ranging and highly consequential.

The existing knowledge gap about the indirect effects of international human rights rulings limits our understanding of the actual effects these rulings have on the ground. The set of country-based case studies, for which this paper provides a theoretical and conceptual framework, highlight the variable potential of the ECtHR judgments to reach and influence the local and national communities that are most centrally concerned. By developing a research agenda to study the indirect effects of the ECtHR judgments, they make a contribution to our knowledge of the Strasbourg judiciary. They also advance the state of research on international courts more broadly, illuminating the role of such courts and their potential to influence domestic politics and societies.

Understanding the indirect effects of international courts has become imperative at a time when both interest in, but also skepticism about these courts has grown, more in Europe than anywhere else. As a recent 
study shows the salience of European courts, the Court of Justice of the European Union (hereby CJEU) and the ECtHR, has grown for the citizens of Europe. The publics' knowledge of and interest in European courts is possibly closely linked to the substantial levels of legitimacy and trust these courts enjoy. Such legitimacy and trust though is likely to vary across countries and to fluctuate in response to unpopular decisions (Voeten 2013; see also Benvenisti 1999; Mancini 2010). The political debates around the potential UK withdrawal from the European Convention on Human Rights pose one conspicuous example. Of broader relevance to the Convention system as a whole is the reform process the Court has been undergoing in recent years, resulting in, amongst other things, a greater emphasis on the principles of subsidiarity and the margin of appreciation.

\section{THE INDIRECT EFFECTS OF COURTS: DECENTERING LAW AND RIGHTS}

How do we understand the indirect effects of courts and why are they significant? An appreciation of courts' indirect effects has grown out of the documented limitations of court rulings in ordering or enforcing significant legal and policy change. Within the context of a welldeveloped American legal scholarship on this issue, scholars have thoroughly questioned the ability of court decisions to bring actual social and policy change on the ground in line with pronounced judicial norms (Rosenberg 1991). Even when they vindicate those pursuing progressive social change, court decisions arguably mete out little more than "hollow hope": they can promote significant legal and social change only when there is ample support from legislative and executive officials, as well as significant elite and public support for their rulings (Rosenberg 1991). As Malcolm Feeley puts it, "the conventional wisdom among political scientists and sociologists who have studied these matters is that the courts by themselves are not very powerful and, at best, are important at the margins or in conjunction with other governmental bodies" (Feeley 1992, 751). The message one gleans is that courts are not always "where it's at': we need a closer look at the margins, and at local and national level developments on matters of religious pluralism (McCann" 1992). ${ }^{6}$

Existing studies show that the domestic policy effects of judgments issued by the ECtHR in the area of religious freedom vary and are 
often limited. In Greece for example, the ECtHR judgments that vindicated religious freedom claims raised by Jehovah's Witnesses (JWs) offered a justification for liberalizing administrative practice and national jurisprudence in the direction of expanding the religious freedom enjoyed by this minority. In the absence of sufficient, domestic political and majority (Orthodox) church support though, they had limited impact on the underlying and restrictive legal frame (Anagnostou and Psychogiopoulou 2013)7. A normative implication underlying the "constrained" view of courts is that as institutions they are on the side of the powers that be, providing support for the status quo but being weak sources for challenging the prevailing order (McCann 2004, 507).

A decentred perspective of law and rights, however, moves away from a focus on a court's ruling ordering policy change, to explore how interested actors view a judicial decision, decipher, and enact its perceived messages. In this tradition of socio-legal analysis, the law is viewed as a cultural institution that forms and transforms via the meanings that people attach to it. Through this lens, law and rights are primarily understood as discursive logics that shape the normative frames through which individual and collective actors conceptualize and seek to address social problems (McCann 1994). ${ }^{8}$

In an early formulation of the constitutive perspective of law and rights, Marc Galanter's seminal contribution referred to "the radiating effects of courts" (Galanter 1983). Galanter proposed a consideration of the centrifugal flow of influence outward from courts and into the wider world (Galanter 1983 , 119). From this perspective, the principal contribution of courts to dispute resolution is the provision of a background of norms and procedures against which negotiations and regulation take place in both private and governmental settings (Galanter 1983, 121): "Courts produce not only decisions, but messages. These messages are resources that parties use in envisioning, devising, pursuing, negotiating, vindicating claims (and in avoiding, defending, and defeating them)" (Galanter 1983, 126).

Other scholars have explored the indirect effects of law and courts specifically in terms of developing a "politics of rights" (Scheingold 2004). A politics of rights develops, for example, when marginalized groups capitalize on perceptions of entitlement associated with particular legal norms in order to initiate social mobilization. While they are neither necessary nor indispensable resources for social movement activism, from this perspective law and rights can potentially transform the tactical landscape in which such activism develops, as well as raise awareness and empower social actors. 
In sum, legal norms and judicial rulings may have various less conspicuous but nonetheless important constitutive effects well beyond policy change: they can alter both the context of social struggles, as well as the strategies and identities of social actors. Court decisions can recast the contours of public debates on an issue by imparting legitimacy on or enhancing the salience of particular kinds of rights claims. They can influence the discursive frames of social movement actors, reconstruct their interests, and at times empower them. At the same time, they can provoke reactionary mobilization to curtail rights' advancements, as has often been the case in legal action related to religion and religious freedom. In these variable and contradictory ways, courts can contribute to the emergence, growth or decline of social movements, not only of progressive but also of conservative ones (McCann 2006). Such largely unintended and often contradictory indirect effects are among the least studied aspects of law and social change.

In the "shadow" of ECtHR religious freedoms cases, judicial enunciations of human rights supply standards and the setting for negotiations and conflicts among the multiplicity of religious, social and state actors active in the field of religion. The nature, extent, and results of the dynamics that emerge are critical to an understanding of the fuller impact of the Court on religious pluralism, which cannot be limitedly focused on implementation or non-implementation of its decisions. As set out in the introduction to this symposium (Fokas), a research agenda on the indirect effects of the ECtHR religion and education judgments raises the following questions: Do different social and religious actors in European states know and pay attention to relevant ECtHR judgments, and how do they perceive them? What kinds of legal, political, and social strategies do they employ, and do their strategies change in response to ECtHR's judgments? Do secularist actors invoke ECtHR case law in their domestic struggles and public discourse around religion and education, and if yes, in what ways do they do so? Last but not least, how do dominant religious actors perceive ECtHR judgments and how do they incorporate their message in framing their views in domestic conflicts around religion and education-if they do at all? Answers to such questions will impart valuable insight into the radiating indirect effects of the Court's case law, and thus also on the Court's impact, or lack thereof (as the case may be) on religious pluralism at the grassroots level. It is the collective aim of the four articles of country-based case studies completing this symposium to address these questions. 


\section{COURT DECISIONS, LEGAL MOBILIZATION AND THE POLITICS OF HUMAN RIGHTS}

ECtHR judgments are authoritative pronouncements of human rights law that define the various manifestations, (shifting) content, and limits of religious freedom and conscience alongside other related rights. As such, they can influence and contribute "by way of a politics of [human] rights" to the emergence or success of a secularist or pluralist movement. A "politics of rights" in Scheingold's classical formulation, develops in the context of campaigns that deploy rights in pursuit of a progressive political agenda, including in regard to religious freedom. Religious freedom norms pronounced in the ECtHR judgments, alongside other human rights, including education and non-discrimination, can be deployed as both discursive and institutional resources. They can help legitimate claims that are raised by different social, legal, political and religious actors in a country and shape their expectations as to the kinds of laws and policies a state ought to adopt in order to ensure religious freedom. Under certain conditions, a politics of human rights can be conducive to the successful attainment of progressive goals at the national or transnational level. In the paragraphs that follow we set out the potential indirect effects of ECtHR case law, thus setting the stage for the empirical research presented in the remaining contributions to this symposium. The empirical countrybased articles explore the extent to and conditions under which this potential is actually achieved at the grassroots level.

What kind of inspiration, awareness, and motivation can ECtHR judgments provide to domestic actors pursuing a secular and pluralist kind of teaching of and about religion in school? The research presented in the articles which follow shows that human rights judgments in some cases influence the mobilization strategies of such actors first by prompting them to engage with law and pursue legal action in national or European courts. In this regard, legal mobilization refers to the invocation of legal rules and conventions (such as rights, constitutional provisions), both substantive and procedural, by an individual or collective actors in courts and in quasi-judicial bodies (i.e. ombudsman institutions). By litigating in court, different actors seek to gain access to various goods, to pressure for change in legal or policy change, and more broadly to regulate, order, legitimate or delimit relations between citizens and the State, as well as relationships between private parties. A large and diverse scholarship shows the benefits and the disadvantages of litigation as a form of strategic action. It also shows that litigation is mostly deployed in 
conjunction with, rather than in the place of, political and other kinds of non-legal action. In the articles that follow we provide examples to this effect based on research conducted in four country contexts-Greece, Italy, Romania, and Turkey.

Legal mobilization is not limited to litigation in courts or to recourse in quasi-judicial bodies (i.e. equality bodies or agencies like the Ombudsman). Indeed, it extends well beyond juridical activity to encompass a wide variety of social and political mobilizations that take place "in the shadow" of court decisions. As the country-based articles in this symposium show, the norms that are pronounced in or inspired by ECtHR judgments around religious freedom, education, or respect for private and family life, are variably invoked by individual or collective actors in the context of advocacy campaigns, public discourse, or grassroots activism, to advocate, and legitimate but also to contest specific demands. What is distinctive specifically about legal mobilization (as opposed to other types of mobilization) is the authority and legitimacy that one (individual, group, viewpoint) draws from appealing to law and judicially pronounced rights to boost one's claims. As it is noted, "rights are a distinctly qualified political resource... When courts validate an expansive interpretation [or rights]... they provide both institutional leverage and discursive legitimation" (Scheingold 2004, 31).

In understanding how judicial decisions related to human rights can influence the perceptions and discourses of the different social and religious actors, an analytically useful notion is that of framing. Framing refers to the contentious processes in which meanings and ideas are both debated and contested, but also negotiated and produced. ${ }^{9}$ Social activists, including those engaging in disputes related to religious freedom, extensively engaged in the construction of collective action frames; namely, the construction of "action-oriented sets of beliefs and meanings that inspire and legitimate the activities and campaigns of a social movement organisation" (Benford and Snow 2000, 614). Framing takes place through contestation as individuals and groups are called to navigate amidst contradictory "sets of ideas that help groups explain, evaluate, and engage the social and political world"; the ideas and frames that prevail may encourage or discourage legal advocacy, rights claiming and resort to courts (Krishnan and Den Dulk 2002, 246). Being sufficiently flexible, inclusive and broad in interpretive scope and cultural resonance, human rights can be seen as a "master frame" in Europe but also globally. 
The field of religion-related mobilization in Europe comprises a highly pluralistic array of actors with diverse views, priorities, and strategies, who are relevant to this study. These include religious minority actors; religious majority actors; representatives of secular, atheist, religious, and other ideological NGOs; "cause lawyers" representing religious freedom cases; human rights organizations; and state representatives dealing with issues related to religion and religious freedom. As demonstrated in the articles that follow, many of these actors have variably been engaging in "frame bridging" (Benford and Snow 2000, 624) in legal action before the Strasbourg Court: they have been linking human rights norms related to religion and religious freedom and conscience with a variety of claims about education, morality, and ethics, anti-discrimination, or minority culture, among others. Such diversification of religion-related claims in the ECtHR suggests that one of the unintended and indirect effects of its judgments has been to instill human rights discourse into a variety of liberal and progressive, but also, at other times, conservative and reactionary religion-related mobilization, in judicial and/or political arenas.

A judicial defeat may also allow social movement actors and litigators to raise consciousness, to mobilize constituents and to dramatize social injustices. It may trigger more aggressive organization, advocacy and direct action on the part of the defeated party by highlighting more intensely the injustice suffered by the group, and the courts' ineffectiveness in redeeming it (NeJaime 2011, 984). Court decisions can be expected to become relevant in contexts of collective mobilization and to contribute to rights awareness primarily among a pre-existing and organized constituency of activists, rather than in the society at large or among isolated individuals (McCann 1994, 111).

If human rights can meaningfully and obviously be construed to advance liberal, rights-expansive claims on behalf of disadvantaged groups, such "bridging" is far less self-evident on behalf of conservative religious actors and claims. Human rights are highly abstract, indeterminate and thus contested principles. As it is noted more broadly, "just as the indeterminacy of rights accommodates their egalitarian expansion, so too can rights be inflected in anti-egalitarian ways" (Scheingold 2004, 33). This has been evidenced in religion-related struggles and debates in North America but also more recently in Europe, as the research showcased in this symposium demonstrates.

Religious conservatives in the United States have successfully mobilized an anti-egalitarian politics of rights. They appropriated the language of rights but they reframed their arguments to reflect an alternative 
understanding of equality itself-in the process constructing a "competing" myth of rights (Den Dulk 2006, 200; see also Fokas 2016). In large part, religious conservatives and status quo actors in the United States started to frame anti-egalitarian claims as rights in response to Supreme Court decisions that expanded rights for minorities and upheld abortion rights in the 1970s but also earlier. Liberal U.S. Supreme Court decisions promoting pluralism and religious freedom heightened concern among Catholics and Evangelicals with what they perceived as the ascendancy of secular humanism and the moral decay of the broader culture (Krishnan and Den Dulk 2002, 253; Hoover and Den Dulk 2004, 18). Overcoming their profound ambivalence about actively engaging in political and social life, Evangelicals began to use the courts and the language of rights in order to defend religious community values, and to curtail liberal advancements (Den Dulk 2006). Against secular and egalitarian adversaries who supported the separation of religion from state and the equal acceptance and recognition of all faiths, religious conservatives argued that the value of equality demanded greater state accommodation of religion in public life (Den Dulk 2006, 205). Thus, norms such as religious freedom and equality were appropriated to advance a conservative agenda invoking morality and a religious way of life. Significantly, the legal activism of Catholics and Evangelicals helped shape a highly active movement and powerfully injected religion into U.S. politics.

ECtHR decisions and judgments can also contribute to the (trans)formation of transnational networks around different issue areas. As we saw in the case of Lautsi, but also in cases related to JWs, legal recourse in the ECtHR often involves the mobilization and participation of a variety of actors such as nationally-based JW organizations, organizations working on religious freedom issues more broadly, public law organizations acting as third party interveners, and academic experts, among others. ECtHR judgments may promote the creation of new or contribute to the buttressing of formerly existing transnational advocacy networks. ${ }^{10}$ These are loosely or more densely associated non-governmental actors motivated primarily by shared principled ideas and values employing "strategies aimed to use information and beliefs to motivate political action and to use leverage to gain the support of more powerful institutions" (Keck and Sikkink 1998, 30). Transnational advocacy networks are significant because they multiply the channels of access to the international system and they also make international resources available to new actors in domestic political and social struggles (Keck and Sikkink 1998, 1). 


\section{RELIGION AND EDUCATION CASE LAW IN THE ECtHR: A TAILORED APPROACH}

The Strasbourg Court has radically changed the context for religious pluralism in Europe (and beyond) through its handling of a large number of issues which are central to the concerns of religious minorities and majorities, but also of many secularist and humanist groups. In its first watershed judgment of Kokkinakis v. Greece ${ }^{11}$ related to religious freedom in 1993, the ECtHR elaborated on the freedom of thought, conscience, and religion (Article 9 ECHR) as one of the foundations of a "democratic society". Since then, the Court's engagement with religion has grown increasingly diverse and has entailed the application of Convention provisions well beyond ECHR Article 9. Over time the case law has evolved from addressing more "classic concerns" around religion stemming from protection of or respect for majority religion through issues such as church tax, blasphemy, and religious education, to an increasing trend to include issues such as bioethics, limitations on religious symbols in public spaces, social ethics, and religious dress in public spaces.

At the heart of the Strasbourg Court's religion-related case law are what Hunter-Henin describes as "tensions between a systemic approach, sensitive to States" heritages and legal frameworks, and an individual approach, more attuned to individual rights and beliefs" (Hunter-Henin 2012, 4). The ultimate resolution of such tensions carries broad-ranging implications for religious and ideological majorities and minorities, whether these are operating in overarching secularist environments or, alternatively, in contexts with differing levels of established religion. ${ }^{12}$

We find such broad-ranging implications in the ECtHR case law specifically on religion and education, impacting the rights of religious minorities in relation to religious majorities; the rights of religious majorities in relation to secular states; and the rights of atheists and secularists living in contexts with established religion. In all four country cases included in this symposium, various minority, secularist, and atheist actors have mobilized and engaged in heated debates against majority religions over whether religion should be taught as part of school curricula. They have also contested the content of religious classes, as well as whether and how national rules can enable students from non-majority faiths and/or atheists to opt out of religious education classes, but also out of sex education classes. How do particular ECtHR judgments influence the opportunities and constraints for such mobilization in different national contexts? Do institutional and 
civil society actors in domestic religion in education conflicts invoke ECtHR case law to frame their views and claims?

The ECtHR's rich repertoire of religion and education cases has in some way (and sometimes in different ways over the years, thus reflecting the Convention as a "living instrument'), addressed most of the current major debates in the field across European countries. One of the earliest cases in this field entailed exemption claims and, specifically, claims to exemption from sex education on the grounds of "offence to religious sensibilities" (Kjeldsen, Busk Madsen and Pedersen v. Denmark, 1976). ${ }^{13}$ Here the European Commission for Human Rights (hereby ECommHR) ${ }^{14}$ found that compulsory sex education in public schools does not violate parental freedom. Ten years later, in Angeleni v. Sweden (1986), the ECommHR declared inadmissible the claim of atheist parents that their daughter should be exempted from the compulsory course in religion at her state-run school, on the grounds that the student had not been subject to any religious indoctrination. ${ }^{15}$ Similarly, in Bernard and Others $v$. Luxembourg (1993), the ECommHR declared inadmissible a claim to the right to exemption from the religious education course because the applicants did not argue that the course in question entailed an exposure to indoctrination and that the course, as taught, conflicted with their philosophical beliefs. ${ }^{16}$ Notably, in Appel-Irrgang and Others v. Germany in $2009,{ }^{17}$ the Court also declared inadmissible the case brought forward by parents calling for an exemption from a mandatory ethics course because they considered the instruction's secular character contrary to their Protestant belief.

One of the most definitive statements by the Court on the exemption, but also on religious education in general, is that found in the case of Folgero v. Norway (2007). ${ }^{18}$ In this case, we also see the intimate link between the issue of exemption and that of the content and nature of the religion courses. The claimants' argument was that the Norwegian public school course in Knowledge about Christianity, Religions and Life Stance (KRL) was so heavily focused on the teaching of Christianity that full exemption must be granted on the grounds of Article 2 of ECHR Protocol 1. The Norwegian state contrarily claimed that the course was non-confessional and knowledge-based, that the disproportionate emphasis on Christianity was appropriate when taking into account Norwegian history and culture, and that the partial exemption scheme in place (allowing exemption from certain parts of the course and certain "clearly religious activities') sufficiently guaranteed the right to education in accordance with parents' religious or philosophical 
beliefs. In Folgero the Court engaged in a detailed assessment of the content of the course and held that the curriculum of KRL gave preponderant weight to Christianity by stating that the object of primary and lower secondary education was to give pupils a Christian and moral upbringing. The Court also found that the partial exemption scheme entailed a heavy burden on the parents to remain informed of the details of the course in order to know when the student ought to be exempted and also risked undue exposure of their private life. It thus rendered the mandatory teaching of the course, without the possibility of full exemption, in violation of the Convention."

In Hasan and Eylem Zengin v. Turkey (2007) $)^{19}$ the claim was also about the content of the religious culture and ethics courses. The Alevi parents of a child argued that the course was taught in a way that praised the Sunni interpretation of the Islamic faith and tradition without providing detailed information about other faiths and was thus a violation of Article 2 of Protocol 1. The claimant also alleged that the compulsory course in religious culture and ethics was incompatible with the principle of secularism. The Court found that the syllabus could not be considered to meet the criteria of objectivity and pluralism, nor to respect the religious and philosophical convictions of the applicant, and that the exemption procedure was inappropriate, and thus found in this case a breach of Article 2 of the first Protocol. In 2014 the Court revisited the same issues, raised by another follower of the Alevi faith, in Mansur Yalcin v. Turkey, again finding a breach of Article 2, Protocol $1 .^{20}$

In 2010 the Court contended with problems that may be faced by school children who are exempted from religious education. Specifically, in Grzelak v. Poland, ${ }^{21}$ the claimants argued that their son suffered from the failure of the public school to organize alternative courses in ethics during the time of the religious course, leaving him both inadequately supervised during that period, and also without a mark in his school report in the place of the religious course. The Court found in favor of the claimants a violation of Article 9 in conjunction with Article 14 (anti-discrimination).

Another problem point in the area of religion and education found in various country contexts and also addressed by the Court's case law has to do with mandatory participation in certain activities, whether religious or patriotic. Here we find JWs leading in much of the related case law, with cases opposing mandatory participation in school parades (Valsamis v. Greece, 1996 22 ; Efstratiou v. Greece, 1996 23 ). In both cases, the Court held that the applicants' pacifist convictions could not have been offended 
by the parade, its purpose, or the arrangements for it and observed that pacifist objectives and the public interest were served in such commemorations of national events. The obligation to take part in the parade did not offend the parents' religious beliefs, and the penalty of suspension did not amount to an interference with the students' freedom of religion.

Also, well-embedded in the ECtHR's repertoire are cases to do with religious symbols in public schools, mainly worn symbols but also, more recently, those displayed. In Dahlab v. Switzerland (2001), ${ }^{24}$ the claim of a primary-school teacher who had converted to Islam to the right to manifest her faith through the wearing a headscarf while teaching was declared inadmissible. The Court held that societies with multiple religions sometimes had to limit religious freedom to "reconcile the interests of the various groups and ensure that everyone's beliefs are respected." It also stated that it was within the government's discretion to prohibit the wearing of headscarves by public school teachers in order to balance these interests, and that the importance of religious neutrality justified the restriction. In 2005, again the Court restricted the right to manifest one's religion through the wearing of the headscarf, but this time of a university student, in Leyla Sahin v. Turkey. ${ }^{25}$ Here then we have a pair of cases with a similar claim, but one of a Muslim minority in a majority Christian context, and the second of a Muslim majority member in a (then) secularist context. (Notably, the same line of reasoning was maintained years later in Dogru v. France $e^{26}$ and Kervanci v. France, ${ }^{27}$ both in 2008, with the Court upholding the state's right to restrict the wearing of the headscarf in public schools). With these cases, the Court opened itself up to criticism that it treats the freedom to manifest Islam, whether in a majority Muslim or Christian setting, as less than worthy of protection. ${ }^{28}$

The criticism of a differential approach grew with the case of Lautsi $v$. Italy. More specifically, it grew with the Grand Chamber's overturning, in 2011, of the 2009 Chamber judgment which had found in favor of the atheist parent's claim that the display of the crucifix on public school walls violated Article 2 of the first Protocol. Here the Court ruled (amongst other things) that the crucifix was sufficiently neutral in the particular context of the Italian school system as to not infringe upon the right to education in accordance with one's religious or philosophical convictions. Lautsi then stands in stark contrast with the pronouncements of non-neutrality of Islam-related symbols. It is also worth noting that the Lautsi case is particularly prone to leave traces in various national and local level settings because of its relatively wide publicity across Europe. 
Finally, issues to do with religious autonomy in the educational arena are also found in contemporary Europe as well as in the ECtHR case law. An important precedent was set in Fernandez Martinez v. Spain, ${ }^{29}$ a case in which a priest who had married and in so doing broke Roman Catholic celibacy vows was effectively dismissed (contract non-renewal) from his post as a teacher of religious education in a public school after having made public his status as a married priest. The Court ruled in favor of the State in its respect of the Catholic Church's autonomy in choosing to not renew the teacher's contract.

Such cases form the backdrop against which the four country case studies presented in this symposium have been played out. As we shall see in the four following contributions, whether and the extent to which human rights law is mobilized in domestic conflicts varies within and across the four countries under study, and so does the extent to which relevant ECtHR judgments have been invoked by religious, secularist, minority or atheist actors.

\section{A RESEARCH AGENDA}

The research presented in this symposium employs a bottom-up approach that contextualizes court judgments within broader processes of religionrelated social mobilization. Its basic aim is to determine levels of religious, political, legal and NGO awareness of, engagement with and uses of ECtHR religion-related judgments. Such an approach includes attention to the various ways that groups and individuals deploy legal resourcesi.e., ECtHR judgments and decisions, including the language of those judgemnts and decisions and the reasoning therein-to wage their campaigns in multiple venues including but also beyond courts. In order to understand why and under what conditions ECtHR judgments can be seized upon as resources to mobilize and empower social and religious actors, we must unravel the local and national conditions and contexts within which they are received and debated, and which may have important similarities or differences across the four country cases. Qualitative indepth interview research with such actors yields critical insight into how, why and under what conditions the Court's religious freedom jurisprudence impacts upon grassroots level mobilizations around religion, and upon religious pluralism as seen in action at the grassroots level.

The domain of religion and education is especially conducive to such a study $^{30}$. This topic allows for insights to be drawn on the secular $v$. the 
religious dimension of case law impact, because both religious and secularist actors actively contribute to the relevant social and political debates. The topic also allows examination of the minority $v$. majority dimension in that religious majorities and religious minorities have vested interests and actively engage in social and political struggles around both the teaching of the majority religion in public schools (and rights to an exemption for minority groups) and the rights to religious minority education in accordance with their own faith. Finally, the subject area has expanded so dramatically beyond the question of the teaching of religion, to include sex education, same-sex education, participation in religious or patriotic rituals, that-against the backdrop of a very rich collection of related ECtHR case law-that a focus on religion and education "in the shadow" of the ECtHR offers special insight into the potential influence of the Court on religious pluralism on the ground in contemporary societies.

In the articles to follow, evidence of the Court's influence on the ground is presented, alongside evidence of its lack of influence in several domains and from one country context to another. The qualitative research presented therein offers a nuanced perspective both on the question, set out above regarding what kind of inspiration, awareness, and motivation an ECtHR judgment can provide to domestic actors pursuing a secular and pluralist kind of teaching of and about religion in school, and on the question of how an ECtHR judgment may be demobilizing for social actors. Take, for example, the case of Lautsi v. Italy: Lautsi's reverberations were powerful both across the four countries studied as well as across issue areas, so that it encouraged majority actors seeking to preserve the status quo, and operated as a demobilizing factor for secularist actors in fields well beyond that of religion and education. In Italy for example, many social actors consulted for the study interpreted the judgment as an indication that the Concordat between the Italian state and the Roman Catholic Church trumps most else, and no challenges to religion-state relations (and to majority religion privileges) would be upheld by the ECtHR. Meanwhile, the same categories of respondents in Romania read in the Lautsi verdict a blow to any minority religious claims.

Besides demobilization, we are also presented in the texts that follow with stark examples of counter-mobilization, as in the Romanian case of a religious activist complaining: "it was a rather brutal entry in this domain...They [the secularists] kept saying that they would take the case to the ECtHR ... After which we started being interested in what 
the ECtHR is, how the ECtHR mechanism works" and thus began preparing for a potential intervention before the Court on the topic at hand.

The texts that follow also provide insight into the powerful role played by judicial defeat. As noted above, a judicial defeat may also allow social movement actors and litigators to raise consciousness, to mobilize constituents and to dramatize social injustices. Of the countries studied in the present collection of articles, nowhere is this dynamic more conspicuous than in the Turkish case, where national judicial defeats have so pointedly mobilized groups to litigate before the ECtHR. And in the aftermath of such ECtHR case law, the Turkish state's failure to implement the decisions has buttressed the development of far more developed networks of actors raising consciousness, mobilizing constituents and dramatizing the injustices in the domain of religion and education.

As will become clear through the following articles, much is contingent on the national legal-political context in which religious actors operate. Again, relations between religion and the state are shaped by deeply ingrained and highly diverse traditions across countries, by varying degrees of tolerance for minority faiths; and by place of religion in public life. We see echoes of each of these factors in the voices of grassroots level actors presented in the four country case studies: the potential role of the ECtHR in each context is often seen through the prism of religion-state relations in each country context, and higher levels of awareness of the "margin of appreciation" leads to lower expectations of changes to the status quo on matters touching on religion-state relations.

Further, as evinced in the research presented as a whole in this symposium, the normative pronouncements contained in ECtHR judgments and decisions are only one among a broader universe of normative principles, with which they may cohere, compete or come into conflict, and which can be invoked in collective mobilization and public discourse. Alternative sources of norms around religious freedom include the national constitution, EU law, national courts and human rights agencies and quasi-judicial bodies (such as the office of the Ombudsman). The latter point serves as a loud cry for the need for empirical, grassroots level understanding of the Court's potential impact, as the radiating effects of the case law will necessarily vary depending on what those alternative sources of norms around religious freedom are in different contexts. Only through comparative study may begin to understand the factors encouraging or inhibiting the transformative potential of Court's pronouncements on religion and education on the ground. 


\section{NOTES}

This article is written in the context of the Grassrootsmobilise Research Programme (http://www. grassrootsmobilise.eu), funded by the European Research Council (ERC, Grant no. 338463). We acknowledge our thanks to the ERC, as well as to the London School of Economics Hellenic Observatory for the support to Effie Fokas during this research. We would also like to thank the journal's anonymous reviewers for their helpful feedback. Please see also the working paper on this topic (Anagnostou and Fokas 2015) for the analytical frame which served as a guide to our research in the Grassrootsmobilise research programme.

1. 'Religious field' is interpreted broadly to include issues that directly implicate faith groups (whether majority or minority) but also issues which relate to deeply-held beliefs and concerns of religious, non-religious, secular and/or secularist, atheist, and humanist groups; the issues may have no direct link to religion per se but may lie more in the realm of social ethics (e.g., same-sex marriage).

2. The ECtHR is not formally a constitutional court, but an international tribunal. However, in its evolution over time, the Strasbourg Court has increasingly performed a role that closely resembles that of constitutional courts. This evolution is reflected in scholarship on the Court presenting it as 'largely, though not fully constitutional'; see Sadurski (2009), 448-449.

3. Partial exceptions include the work of Cichowski (2007; 2013), Richardson and Lee (2014), and Van den Eynde (2013), while the work of Fokas $(2015 ; 2016)$ is more focused specifically on the indirect effects of ECtHR case law, in the domain of religion. Meanwhile, Michael Goldhaber's A People's History of the European Court of Human Rights (2009) explores indirectly the mobilizing potential of that court's case law.

4. Also critical here is the fact that the U.S. Supreme Court is a national court while the ECtHR is an international court, a difference which carries significant implications for potential public legitimacy. See Alter, Helfer and Madsen 2016; see also Fokas (2017a)

5. 'Religion' is notoriously difficult to define. In the present paper, the word is used very loosely to refer also to conscience or belief (as the three notions are presented together in Article 9 of the ECHR).

6. See Fokas (2015) for further development of this argument in relation to the Grassrootsmobilise research programme (http://www.grassrootsmobilise.eu).

7. Here a nuanced perspective is required: while the JW case law did not result in a change to the legal framework, for example, banning proselytism (which was behind the watershed Kokkinakis case), it did lead to a change in policies in terms of how administrative and judicial authorities applied the relevant provisions. See Fokas (2017b); see also Fokas forthcoming.

8. See also the debate with Rosenberg, in Rosenberg (1992).

9. For an overview of a sizeable social movement scholarship on framing, see Benford and Snow (2000).

10. For more on third party interventions and transnational networks around the ECtHR, see Fokas (2016).

11. ECtHR, Kokkinakis v. Greece, App. No. 14308/88, May 25, 1993.

12. Establishment of religion entails state official recognition and support of a particular religious institution as a national institution.

13. ECtHR, Kjeldsen, Busk Madsen and Pedersen v. Denmark, App. Nos. 5095/71; 5920/72; 5926/ 72, December 7, 1976.

14. Between 1959 and 1992, cases related to the right to religious freedom were dealt with exclusively by the European Commission of Human Rights and not by the Court. In 1998, the introduction of Protocol 11 abolished the two-tiered system and the European Commission of Human Rights filtering, establishing a single Court.

15. ECommHR, Angeleni v. Sweden, App. No. 10491/83, December 3, 1986.

16. ECommHR, Bernard and Others v. Luxembourg, App. No. 17187/90, September 8, 1993.

17. ECtHR, Appel-Irrgang and Others v. Germany, App. No. 45216/07, October 6, 2009.

18. ECtHR, Folgero v. Norway, App. No. 15472/02, June 29, 2007.

19. ECtHR, Hasan and Eylem Zengin v. Turkey, App. No. 1448/04, October 9, 2007.

20. ECtHR, Mansur Yalçin and Others v. Turkey, App. No. 21163/11, September16, 2014.

21. ECtHR, Grzelak v. Poland, App. No. 7710/02, November 22, 2010.

22. ECtHR, Valsamis v. Greece, App. No. 21787/93, December 18, 1996.

23. ECtHR, Efstratiou v. Greece, App. No. 24095/94, December 18, 1996.

24. ECtHR, Dahlab v. Switzerland, App. No. 42393/98, February 15, 2001. 
25. ECtHR, Leyla Şahin v. Turkey, App. No. 44774/98, November 10, 2005.

26. ECtHR, Dogru v. France, App. No. 27058/05, December 4, 2008.

27. ECtHR, Kervanci v. France, App. No. 31645/04, December 4,2008.

28. For an excellent analysis of Islam related cases and discussion of discrepancies between the Court's handling of Christianity and Islam, see Durham et al. (2012).

29. ECtHR, Fernández Martínez v. Spain, App. No. 56030/07, June 12, 2014.

30. For information about other domains studied in the $[\mathrm{xxx}]$ project, see [withheld for blind review].

\section{REFERENCES}

Alter, Karen J. 2014. The New Terrain of International Law - Courts, Politics, Rights. Princeton: Princeton University Press.

Alter, Karen, Laurence Helfer, and Mikael Rask Madsen. 2016. "How Context Shapes the Authority of International Courts." Law and Contemporary Problems 79(1):1-36.

Anagnostou, Dia, ed. 2013. The European Court of Human Rights: Implementing Strasbourg's Judgments on Domestic Policy. Edinburgh: Edinburgh University Press.

Anagnostou, Dia, and Effie Fokas. 2015. "The 'radiating effects' of the European Court of Human Rights on social mobilisations around religion in Europe - an analytical frame". Grassrootsmobilise working paper accessible online at http://grassrootsmobilise.eu/wpcontent/uploads/2017/05/GRM-Working-Paper-1-Radiating-Effects.pdf.

Anagnostou, Dia, and Evangelia Psychogiopoulou. 2013. "Under What Conditions do National Authorities Implement the ECtHR's Rulings?.” In The European Court of Human Rights: Implementing Strasbourg's Judgments on Domestic Policy, ed. Dia Anagnostou. Edinburgh: Edinburgh University Press, 143-165.

Benford, Robert D., and David Snow. 2000. "Framing Processes and Social Movements: An Overview and Assessment". Annual Review of Sociology 26(1):611-639.

Benvenisti, Eyal. 1999. "Margin of Appreciation, Consensus, and Universal Standards". International Law and Politics 31(4):843-854.

Cassel, Douglass. 2001. "Does International Human Rights Law Make A Difference?". Chicago Journal of International Law 2(1):121-136.

Cichowski, Rachel. 2007. The European Court and Civil Society - Litigation, Mobilization and Governance. Cambridge: Cambridge University Press.

Cichowski, Rachel. 2013. "Civil Society and the European Court of Human Rights." In The European Court of Human Rights Between Law and Politics, eds. Jonas Christoffersen and Mikael Rask Madsen. 2nd ed. Oxford: Oxford University Press, 77-97.

Den Dulk, Kevin R. 2006. "In Legal Culture, but Not of It: The Role of Cause Lawyers in Evangelical Legal Mobilization”. In Cause Lawyers and Social Movements, eds. Austin Sarat and Stuart A. Scheingold. Stanford: Stanford University Press, 197-219.

Durham Jr., W. Cole, Rik Torfs, David M. Kirkham and Christine Scott, eds. 2012. Islam, Europe and Emerging Legal Issues. Farnham/Burlington: Ashgate.

Evans, Carolyn. 2001. Freedom of Religion Under the European Convention on Human Rights. Oxford: Oxford University Press.

Evans, Carolyn, and Christopher Thomas. 2006. "Church-State Relations in the European Court of Human Rights". Brigham Young University Law Review 2006(3):699-725.

Evans, Malcolm. 2008. "Freedom of Religion and the European Convention on Human Rights: Approaches, Trends and Tensions". In Law and Religion in Theoretical and Historical Context, eds. Peter Cane, Carolyn Evans and Zoe Robinson. Cambridge: Cambridge University Press, 291-316.

Feeley, Malcolm M. 1992. "Hollow Hopes, Flypaper, and Metaphors". Law \& Social Inquiry 17(4):745-760. 
Fokas, Effie. 2015. "Directions in Religious Pluralism in Europe: Mobilizations in the Shadow of European Court of Human Rights Religious Freedom Jurisprudence". Oxford Journal of Law and Religion 4(1):54-74.

Fokas, Effie. 2016. "Comparative Susceptibility and Differential Effects on the Two European Courts: A Study of Grasstops Mobilizations Around Religion", Oxford Journal of Law and Religion, 5:541-574.

Fokas, Effie. 2017a. The European Court of Human Rights at the Grassroots Level: Who Knows What About Religion at the ECtHR, and to What Effects?', Religion, State and Society, 45:3-4.

Fokas, Effie. 2017b. "Kokkinakis at the Grassroots Level”, Religion \& Human Rights 12 (2-3):210-222.

Fokas, Effie. 2017. "God's Advocates: The Multiple Fronts of the war on Blasphemy in Greece." In Blasphemy and Freedom of Expression: Comparative, Theoretical and Historical Reflections After the Charlie Hebdo Massacre, eds. Jeroen Temperman and Andras Koltay. Cambridge: Cambridge Univ. Press, 389-410.

Galanter, Marc. 1983. "The Radiating Effects of Courts". In Empirical Theories About Courts, eds. Keith O. Boyum and Lynn M. Mather. New York: Longman, 117-142.

Goldhaber, Michael. 2009. A People's History of the European Court of Human Rights, New Brunswick, NJ: Rutgers University Press.

Hillebrecht, Courtney. 2012. "Implementing International Human Rights Law at Home: Domestic Politics and the European Court of Human Rights". Human Rights Review 13(3):279-301.

Hunter-Henin, Myriam. 2012. "Introduction. Religious Freedoms in European Schools: Contrasts and Convergence". In Law, Religious Freedoms and Education in Europe, ed. Myriam Hunter-Henin. Farnham, Surrey: Ashgate, 1-33.

Hoover, Dennis R., and Kevin, and R. den Dulk. 2004. "Christian Conservatives Go to Court: Religion and Legal Mobilization in the United States and Canada". International Political Science Review 25(1):9-34.

Johnson, Timothy R., and Andrew D. Martin. 1998. "The Public's Conditional Response to Supreme Court Decisions". American Political Science Review 92(2):299-310.

Keck, Margaret, and Kathryn Sikkink. 1998. Activists Beyond Borders - Advocacy Networks in International Politics. Ithaca: Cornell University Press.

Keller, Helen, and Alec Stone Sweet, eds. 2008. A Europe of Rights - The Impact of the ECHR on National Legal Systems. Oxford: Oxford University Press.

Krishnan, Jayanth K., and Kevin R. den Dulk. 2002. "So Help Me God: A Comparative Study of Religious Interest Group Litigation". Georgia Journal of International and Comparative Law 30(2):233-275.

Mancini, Susanna. 2010. "The Crucifix Rage: Supranational Constitutionalism Bumps Against the Counter-Majoritarian Difficulty". European Constitutional Law Review 6(1), 6-27.

McCann, Michael. 1992. "Reform Litigation on Trial". Law \& Social Inquiry 17(4):715-743.

McCann, Michael. 1994. Rights at Work - Pay Equity Reform and the Politics of Legal Mobilization. Chicago: University of Chicago Press.

McCann, Michael. 2004. "Law and Social Movements". In The Blackwell Companion to Law and Society, ed. Austin Sarat. Oxford: Blackwell, 506-522.

McCann, Michael. 2006. "Law and Social Movements: Contemporary Perspectives". Annual Review of Law and Social Science 2(1):17-38.

NeJaime, Douglas. 2011. "Winning Through Losing”. Iowa Law Review 96(3):941-1012.

Richardson, James T. 2015. "Managing Religion and the Judicialization of Religious Freedom". Journal for the Scientific Study of Religion 54(1):1-19. 
Richardson, James T., and Brian M. Lee. 2014. "The Role of the Courts in the Social Construction of Religious Freedom in Central and Eastern Europe". Review of Central and East European Law 39(3/4):291-313.

Ringelheim, Julie. 2012. "Rights, Religion and the Public Sphere: The European Court of Human Rights in Search of A Theory?". In Law, State and Religion in the New Europe: Debates and Dilemmas, eds. Lorenzo Zucca and Camil Ungureanu. Cambridge: Cambridge University Press, 283-306.

Ringelheim, Julie. 2014. "Du Voile Au Crucifix: La Neutralité Confessionnelle de l'Etat Dans La Jurisprudence de La Cour Européenne Des Droits de L'homme". CRIDHO Working Paper, Université catholique de Louvain, accessible online at http://cridho. uclouvain.be/documents/Working.Papers/CRIDHO-WP-2014-1-JRingelheim-DuVoile AuCrucifix.pdf.

Rosenberg, Gerald. 1991. The Hollow Hope: Can Courts Bring About Social Change?. Chicago: University of Chicago Press.

Rosenberg, Gerald. 1992. "Hollow Hopes and Other Aspirations: A Reply to Feely and McCann". Law and Social Inquiry 17(4):761-778.

Sadurski, Wojciech. 2009. "Partnering with Strasbourg: Constitutionalisation of the European Court of Human Rights, the Accession of Central and East European States to the Council of Europe, and the Idea of Pilot Judgments". Human Rights Law Review 9(3):397-453.

Scheingold, Stuart A. 2004. The Politics of Rights - Lawyers, Public Policy, and Political Change, 2nd ed. Ann Arbor: University of Michigan Press.

van den Eynde, Laura. 2013. 'An Empirical Look at the Amicus Curiae Practice of Human Rights NGOs Before the European Court of Human Rights' Netherlands Quarterly of Human Rights 31(3):271-313.

Voeten, Erik. 2013. "Public Opinion and the Legitimacy of International Courts". Theoretical Inquiries in Law 14(2):411-436. 